\title{
Плеханова О.В. \\ Психологическая роль социальной рекламы в решении социальных проблем
}

Рязанский государственный университет имени С.А. Есенина (Россия, Рязань)

doi: 10.18411/trnio-09-2021-71

\section{Аннотация}

Статья посвящена проблеме решения социальных проблем средствами социальной рекламы на примере компании DOVE. Подчеркивается, что социальная реклама выделяет не только значимую проблему, но и пытается сформировать образ социально ответственного поведения. Отмечается, что коммерческие организации все больше проявляют интерес к социальным проблемам общества, создавая свои проекты поддержки под именем бренда. Делается вывод, что основная идея проектов компании - это дать психологическую возможность подросткам, а также взрослым полюбить свою естественную внешность и почувствовать себя индивидуальным.

Ключевые слова: социальная реклама, психологическое воздействие, социальные проблемы, манипуляция, бренд, стереотипы.

\section{Abstract}

The article is devoted to the problem of solving social problems by means of social advertising on the example of DOVE. It is emphasized that social advertising highlights not only a significant problem, but also tries to form an image of socially responsible behavior. It is noted that commercial organizations are increasingly showing interest in social problems of society, creating their support projects under the brand name. It is concluded that the main idea of the company's projects is to give a psychological opportunity to teenagers, as well as adults, to fall in love with their natural appearance and feel like an individual.

Keywords: social advertising, psychological impact, social problems, manipulation, brand, stereotypes.

В настоящее время много внимания уделяется роли социальной рекламы в жизни общества. Необходимость решения общественных проблем повышает значимость социальной рекламы и ставит задачи для ее дальнейшего развития. Данный вид рекламы является неотъемлемой частью нашей жизни, ее сила - в умении обратиться к собственной силе человека. Решение любой социальной проблемы предполагает наличие достаточной информации о ней. Одним из средств, позволяющих решить социальные проблемы, является социальная реклама.

Термин “социальная реклама" появился в США в начале XX века, начали создаваться различные плакаты, в которых освещались социальные проблемы общества того времени. Именно с этого момента изменилось понимание рекламы в целом, произошел переворот. В 1906 г. “Американская гражданская ассоциация” создала первую рекламу на тему защиты Ниагарского водопада. В России стимулом для создания социальной рекламы послужила Первая мировая война. В 1995 г. в России появился Рекламный совет, целью которого являлось создание рекламы по социально-важным вопросам. Члены данной организации сами разрабатывали социальные кампании для СМИ и занимались выпуском видео роликов и аудио сообщений. Основной тематикой являлись взаимоотношения в семье, а также отношения к жизни. Термин социальная реклама используется только в России. Во всем мире привыкли использовать термины некоммерческая реклама и общественная реклама.

Социальная реклама направлена на изменение отношения к различным социально важным проблемам. Исследователи отмечают, что крайне важно различать понятия 
“воздействие” и “манипуляция”, а также, что наиболее эффективной будет считаться та реклама, восприятие которой достигается помимо воли человека, напрямую воздействуя на его подсознание. Благодаря методам убеждения и аргументации, реклама подталкивает человека к действиям.

DOVE - это американский бренд, принадлежащей компании Unilever, занимающийся производством средств для личной гигиены. Цель компании - создание качественной продукции товаров массового потребления.

Руководители компании говорят о том, что они стремятся оказывать положительное влияние на общество с помощью добровольных пожертвований в фонд помощи UnileverFoundation, различных социальных проектов, проектов по защите окружающей среды, а также через взаимоотношения с партнерами. Продукты компании продаются не менее чем в 150 странах. Dove позиционируют себя как брэнд не только для женщин, но еще для мужчин и младенцев. Бренд считается самым большим в мире, который производит средства личной гигиены и имеет самый высокий объем продаж туалетного мыла во всем мире.

Логотип Dove - это силуэтный профиль одноименной птицы бренда - голубь, он символизирует собой птицу, которая несет мир.

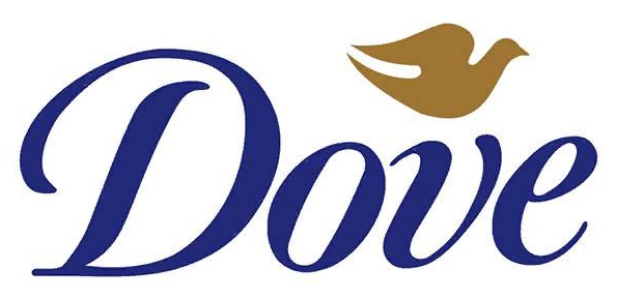

Рисунок 1. Логотип компании Dоvе

Компания Dove впервые появилась в США в 1956 года, когда во время военных событий появилась необходимость ухода за кожей солдат, которые получили серьезные ожоги. Создателям удалось это сделать, и вскоре на свет появилось первое мыло, способное деликатно очищать обожжённую кожу солдат. Мыло производилось из растительных масел и жиров, без содержания щелочи, делая его текстуру достаточно плотной, а секрет состоял в том, что в состав входил увлажняющий крем. Продукт сразу пришелся по вкусу потребителю, что позволило бренду сделать свое имя.

Бренд призывал бороться со стереотипами красоты, которые активно навязывают нам СМИ. Совместно с Unilever, было проведено исследование, в рамках которого было выявлено, что только $12 \%$ женщин удовлетворяет своя внешность, и лишь $2 \%$ довольны собой. Остальные 86\% считают себя некрасивыми. Campaign og Real Beauty выпустила ролик "Evolution", который был удостоен множества наград, в том числе и “Золотого льва". Героем ролика стала девушка, которой делали make-up для рекламы косметической фирмы. Создатели ролика показали весь процесс, который проходит перед тем, как фотографию поместят на обложку. Посыл рекламной кампании заключался в том, что девушка на обложке не имеет ничего общество с собой настоящей. 


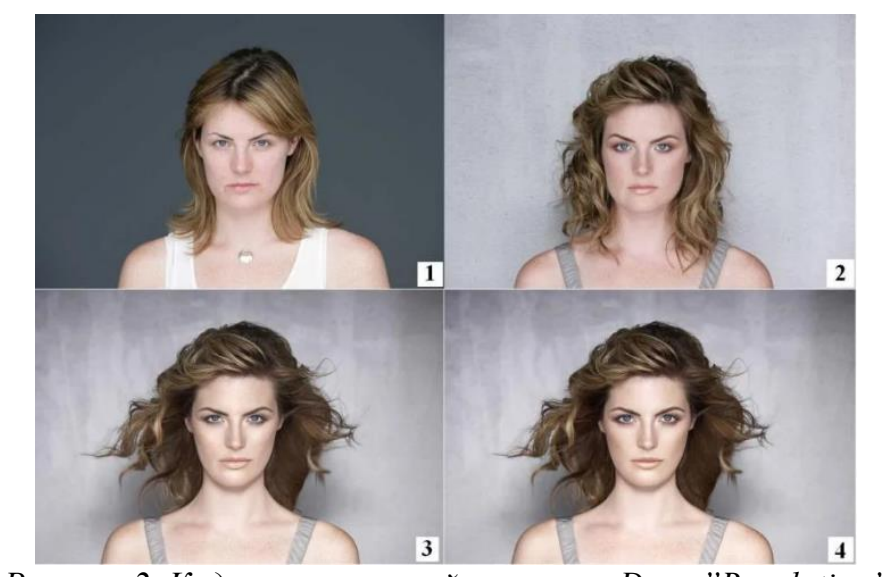

Рисунок 2. Кадр из сочиальной кампании Dove "Revolution”

Следующий проект носит название “Покажите нас”. Его суть - добиться разнообразия женских образов в рекламе и СМИ. Согласно проведенным опросам компании, большинство девушек (примерно 54\%) чувствуют беспокойство из-за навязанных обществу стереотипов красоты. Под руководством компании "Girlgaze" была реализована съемка различных девушек и женщин из 30 разных стран мира. Особенностью данного проекта послужило то, что фотографии девушек выкладывались без ретуши и обработки. Создатели, таким образом, хотели подчеркнуть индивидуальность каждой девушки.

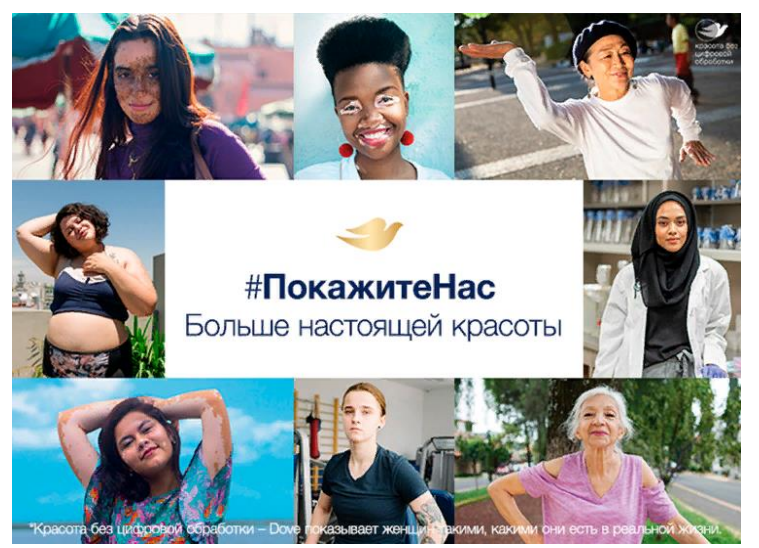

Рисунок 3. Социальная кампания "Покажите нас". Dove

Совместно с Unilever был проведен социальный опрос (Табл.1), сутью которого было проанализировать отношение девушек к своей внешности, а также было выявлено, что более $60 \%$ девочек избегают из-за этого посещение некоторых общественных мест. В опросе принимали участие девочки от 11 до 14 лет. Психологи бренда разработали целую методику по борьбе с низкой самооценкой девочек. Данную методику адаптировали в том числе и на Россию. Суть проекта - посещение профессиональными психологами школ и интернатов, проведение различных тренингов, с целью освободить детей от навязанных стереотипов красоты.

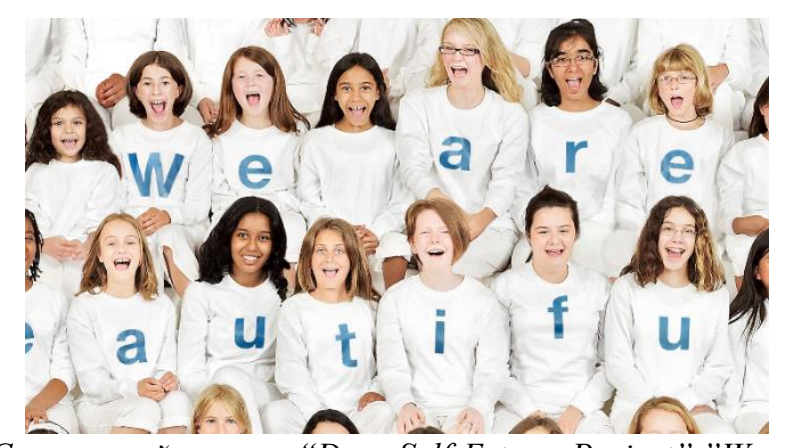

Рисунок 4. Сойиальный проект "Dove Self-Esteem Project" "We are beautiful" 
На протяжении 60 лет бренд Dove помогает всем девушкам почувствовать свою красоту и индивидуальность. В настоящее время компания распространяет хештег \#МояКрасотаМоиПравила и старается держать за собой заданную планку. Под этим хештегом было запущено множество видео роликов как в интернете, так и на ТВ. Героини роликов - самые обычные девушки. Однако в них присутствует огромная сила, они обладают особым видением своей красоты, а также не стесняясь рассказывают свои истории. По данным опроса, около $62 \%$ женщин хотели бы видеть в рекламе настоящую красоту, ту, что дала природа. Компания Dove призывает именно к этому, показывая пример собой.

Проанализировав все социальные кампании бренда, можно сделать вывод, что главная цель Dove - разрушение прочных стереотипов, которые сложились в обществе. Очень важно отметить грамотность выстроенной рекламной кампании для девочек и их мам. По моему мнению, это очень интересный стратегический ход: таким образом, бренд одной рекламой охватывает огромную аудиторию. Приглашенные психологи для девочек от компании Dove говорит о том, что бренд не просто выпускают ролики, чтобы повысить свой имидж, они заботятся о подрастающем поколении.

Идея принимать себя настоящей, неидеальной идет наряду с проблемой принятия других. Если проблему, которая стоит в корне устранить, то все вопросы, которые сопрягаются с ней, исчезнут: жестокое обращение подростков со сверстниками, психологическое насилие в школах и интернатах, уменьшится процент детского суицида. Компания понимает, что непринятие себя или других из-за внешних особенностей, влечет за собой массу других последствий. Социальную рекламу Dove относят к лучшим рекламным проектам XXI века.

В настоящее время все крупные бренды занимаются разработкой общественных проектов. Социальная реклама начала играть роль своеобразного симбиоза коммерческого маркетинга с социальным оттенком. Это происходит, потому что некоторые компании создают социальную рекламу с целью привлечь внимание к бренду, эмоционально привязывать его к потребителю.

$$
* * *
$$

1. Албенова по И.Ф. по Социальные по технологии: по теория по и по практика по// по Социальная по работа: nо история по теории по и по технологии: по сб. по науч. по тр. по Ярославль: по Диа-Пресс, по 2017.- С. nо 93 no - no 103.

2. Веселов, по С. по Оценка по эффективности по рекламной по деятельности по о // по Рекламные по технологии. № - -- 2015. no - no № 5. no - no С. no 2 no - no 4.

3. Волошин, по П. по Сети по социальной по рекламы nо по // по Рекламный по мир. nо -2018.-№ 4.- С. no 10-12.

4. Еляков поА.Д. n Современная по информационная по революция по // nо Социологические по исследования. no - 2011. no - №10. no - C. no 29 no - no 38.

5. Уэллс, nо У. по Реклама: по принципы по и по практика по . - по СПб.: по Питер, по 2016. no - no 735 nо с.

6. Николайшвили Г.Г. Социальная реклама: теория и практика. М.: АСПЕКТ ПРЕСС, 2008 [Электронный pecypc] URL: https://www.studmed.ru/nikolayshvili-g-g-socialnaya-reklama-teoriya-i-praktika_e309be9ae23.html (дата обращения:10.08.2021)

7. Проект Dove по повышению самооценки [Электронный ресурc] URL: https://www.dove.com/ru/home.html (дата обращения:10.08.2021)

\section{Пронина А.Н. \\ Изучение внешних и внутренних мотивов учебной деятельности современных старшеклассников}

Елецикий государственный университет им. И.А. Бунина

(Россия, Елеи)

doi: 10.18411/trnio-09-2021-72

Аннотация

Внешние и внутренние мотивы учебной деятельности старшеклассников являются структурным компонентом данной деятельности и обеспечивают её эффективность. 